\title{
Lipid droplets and the transcriptome of Mycobacterium tuberculosis from direct sputa: a literature review
}

\author{
Daniel Mekonnen ${ }^{1,2^{*}}$ D, Awoke Derbie ${ }^{1,2,3}$, Adane Mihret ${ }^{4,5}$, Solomon Abebe Yimer ${ }^{6,7}$, Tone Tønjum ${ }^{6,8}$, Baye Gelaw ${ }^{9}$,
} Endalkachew Nibret ${ }^{2,10}$, Abaineh Munshae ${ }^{2,10}$, Simon J. Waddell ${ }^{11}$ and Abraham Aseffa ${ }^{4}$

\begin{abstract}
Mycobacterium tuberculosis (Mtb), the main etiology of tuberculosis (TB), is predominantly an intracellular pathogen that has caused infection, disease and death in humans for centuries. Lipid droplets (LDs) are dynamic intracellular organelles that are found across the evolutionary tree of life. This review is an evaluation of the current state of knowledge regarding Mtb-LD formation and associated Mtb transcriptome directly from sputa.

Based on the LD content, Mtb in sputum may be classified into three groups: LD positive, LD negative and LD borderline. However, the clinical and evolutionary importance of each state is not well elaborated. Mounting evidence supports the view that the presence of LD positive Mtb bacilli in sputum is a biomarker of slow growth, low energy state, towards lipid degradation, and drug tolerance. In Mtb, LD may serve as a source of chemical energy, scavenger of toxic compounds, prevent destruction of Mtb through autophagy, delay trafficking of lysosomes towards the phagosome, and contribute to Mtb persistence. It is suggest that LD is a key player in the induction of a spectrum of phenotypic and metabolic states of Mtb in the macrophage, granuloma and extracellular sputum microenvironment. Tuberculosis patients with high proportion of LD positive Mtb in pretreatment sputum was associated with higher rate of poor treatment outcome, indicating that LD may have a clinical application in predicting treatment outcome.

The propensity for LD formation among Mtb lineages is largely unknown. The role of LD on Mtb transmission and disease phenotype (pulmonary TB vs extra-pulmonary TB) is not well understood. Thus, further studies are needed to understand the relationships between LD positivity and Mtb lineage, Mtb transmission and clinical types.
\end{abstract}

Keywords: Mycobacterium, Sputum, Tuberculosis, Lipid droplet, Transcriptome, Host-pathogen interaction, Transmission, Treatment outcome, Lineage

\section{Introduction}

\section{Mycobacterium tuberculosis}

The genus Mycobacterium encompassed over 170 species and the pathogenic species are classified in to three: Mycobacterium tuberculosis complex (MTBC:

\footnotetext{
* Correspondence: nigusdaniel@gmail.com

'Department of Medical Microbiology, College of Medicine and Health Sciences, Bahir Dar University, Bahir Dar, Ethiopia

${ }^{2}$ Institute of Biotechnology, Bahir Dar University, Bahir Dar, Ethiopia

Full list of author information is available at the end of the article
}

Mycobacterium tuberculosis, Mycobacterium africanum, Mycobacterium bovis, Mycobacterium microti, Mycobacterium canettii, Mycobacterium caprae), Mycobacterium leprae and M. ulcerans. Among the species in MTBC, Mycobacterium tuberculosis $(M t b)$ is the main etiological agent of tuberculosis (TB) and is an intracellular pathogen that has ravaged humanity for centuries [1]. The evolutionary success of $M t b$ is attributed to its ability to flip-flop between different metabolic/phenotypic states, adaptation to diverse microenvironments, inhibition of

(c) The Author(s). 2021 Open Access This article is licensed under a Creative Commons Attribution 4.0 International License, which permits use, sharing, adaptation, distribution and reproduction in any medium or format, as long as you give appropriate credit to the original author(s) and the source, provide a link to the Creative Commons licence, and indicate if changes were made. The images or other third party material in this article are included in the article's Creative Commons licence, unless indicated otherwise in a credit line to the material. If material is not included in the article's Creative Commons licence and your intended use is not permitted by statutory regulation or exceeds the permitted use, you will need to obtain permission directly from the copyright holder. To view a copy of this licence, visit http://creativecommons.org/licenses/by/4.0/ The Creative Commons Public Domain Dedication waiver (http://creativecommons.org/publicdomain/zero/1.0/) applies to the data made available in this article, unless otherwise stated in a credit line to the data. 
phagolysosome fusion, and formation of necrotic granuloma [2, 3]. More than $24.8 \%$ of the global human population may harbor $M t b$ [4] in different fatty tissues [5] in the form of latent TB. Ten million active infections and 1.4 million deaths were reported in 2019 [6]. The lipidrich sputum, and its source pulmonary granuloma microenvironment carries phenotypically heterogeneous population of $M t b$ [7].

\section{Lipid and lipid droplet in M. tuberculosis}

Lipid is an inclusive term for fats and lipoids. Lipids include all of the alcohol ether soluble constituents of protoplasm such as fats, oils, waxes and several complex lipids (phospholipids, glycolipids, sulfolipids, aminolipids, chromolipids, and fatty acids) [8, 9]. Mycobacteria contain different types of structural $[10,11]$ and nonstructural [12] lipids. Lipids are a major source of energy [13] and play a vital role in virulence, pathogenicity, and persistence [3]. Unlike other prokaryotes, $60 \%$ of $M t b$ cell-wall constituents are lipids, mainly mycolic acids. Moreover, $40 \%$ of the dry weight of mycobacteria is derived from lipids. $M t b$ stores its chemical energy in the form of neutral lipids by forming emulsion vesicles inside the aqueous phase cytoplasm [14]. In general, lipids are the rations, attire and armor of $M t b$ [15]; as such, the diagnosis, treatment, drug resistance [16] and immunological lifecycle of $M t b$ [17] is heavily relies on membrane and/or cytoplasmic lipids.

Cells store excess lipids inside the cytoplasm and this stored lipid is known by different names depending on the type of cells and tissue. These names includes lipid droplet (LD), lipid body (LB), intracellular lipid inclusions (ILI), oil body (OB), adiposome, spherosome and oleosome. Lipid droplets are pervasive and dynamic subcellular organelles of diverse morphological and functional diversity [18-21] across evolutionary tree of life. Lipid droplets comprised of a hydrophobic core of neutral lipids (triacylglycerol, TAG and cholesterol ester, $\mathrm{CE})$ surrounded by a phospholipid monolayer of phosphatidylcholine (PC), phosphatidylethanolamine (PE), phosphatidylinositol (PI) and lyso-phospholipids; decorated with different types of proteins such as Perilipins (PLIN) [22, 23] (Fig. 1). For a detailed understanding regarding the (cell) biology and biophysics of LD, readers are advised to refer these excellent reviews [26, 27].

It was demonstrated that the LD of $M t b$ is derived from host fatty acids and that isocitrate lyase (encoded by $i \mathrm{cl}$ ) is the responsible enzyme that catabolizes fatty acids (FA) through glyoxylate cycle. Triacylglycerol synthase 1 (coded by $\operatorname{tgs} 1$ ) is the primary enzyme involved in triacylglycerol (TAG) synthesis and that the deletion of the tgs 1 gene led to complete loss of TAG accumulation by $M t b$ [28]. The role of sputum derived LD positive $M t b$ in treatment outcome and transmission has been demonstrated [29]. The presence of LD-positive $M t b$ bacilli in sputum is a biomarker of slow growth, low energy state, lipid degradation, anaerobic metabolism, and non-mutational drug tolerance. Sputumderived LD-positive $M t b$ transcriptome data reveals distinct patterns of gene expression; displaying up- and down-regulation of specific metabolic pathways in sputum microenvironment. In general, the LD profile and transcriptome of $M t b$ directly from sputa are real-time metabolic, phenotypic and physiological markers of the $M t b$ population diversity and dynamics. However, the relationships between $M t b$ LD with $M t b$ lineages, $M t b$ transmission capacity and clinical pathology (i.e., pulmonary TB vs extra pulmonary $\mathrm{TB}$ ) are not well studied or understood. We hypothesize that LD-loaded $M t b$ cells in sputum are like "rocket blast off for planned orbital mission". Thus, this review synthesized the current state of $M t b$ LD knowledge and showed gaps for fueling future areas of research.

\section{Advent of $M$. tuberculosis lipid droplet research}

The presence of fatty material inside the cytoplasm of prokaryotic cells was first demonstrated in 1946 by Burdon using the technique of Sudan black intracellular staining [30]. According to this classic experiment, noticeable amounts of LD were found in the majority of studied bacteria [30]. At that time, more LDs were observed in saprophytic and Mycobacterium leprae than in $M t b$ species [30]. With the aim of determining the precise organization of lipids in the envelope domain of living Mycobacteria, Christensen et al 1999 [31] developed an improved (fluorescent lipophilic probes) technique that is less disruptive than detergents [32] or ultrasonication [33]. After probe labeling of cultivated $M t b$, cells were observed by phase-contrast and epifluorescence microscopy. Using this technique, distinct lipid domains of Mycobacteria were visualized, including the envelope and LDs [31]. Generally, the lipid domains of Mycobacteria are comprised of three parts; the annular envelope, internal peripheral deposits contiguous with the envelope, and distinct LDs that are not associated with the envelope [31].

Following Burdon [30] and Christensen et al [31], Garton and colleagues [29] advanced the field through biochemically characterizing LD in M. smegmatis and $M t b$, and by analyzing factors affecting lipid formation, and the synthesis pathways in these mycobacterial species. The effects of various chemicals and growth conditions on LD were examined using Youmans' and Middle brook $7 \mathrm{H} 10$ culture medias. Cells were stained with Auramine-O followed by Nile red and then stained regions were detected by epifluorescence microscope. Images were captured using a microcomputer controlled CCD camera [29]. The findings showed that, in low- 


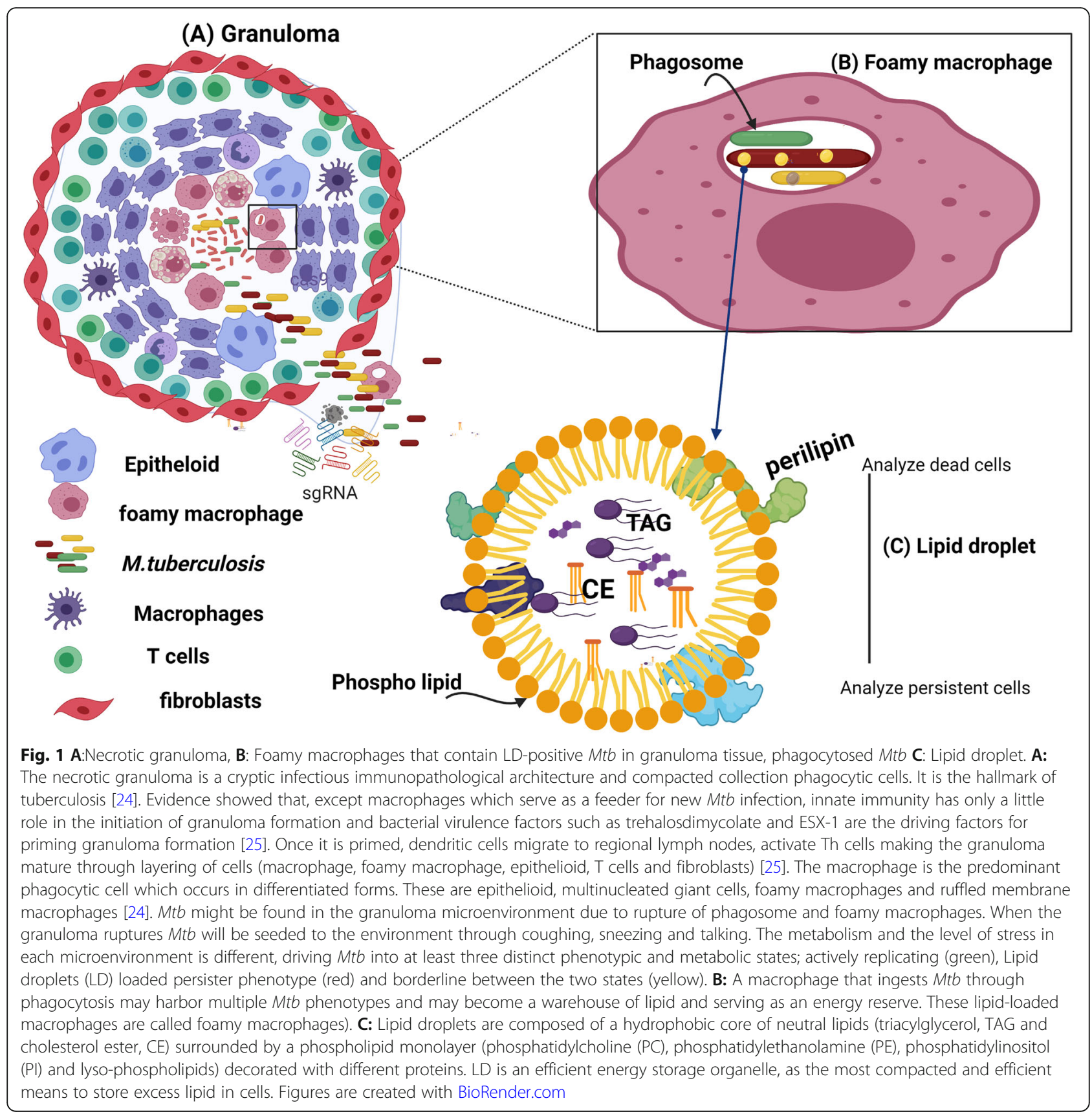

carbon Youmans' broth (YB), M. smegmatis showed high annular pattern and low level of LD. In contrast, in lownitrogen $\mathrm{YB}$, the annular labelling was lost and prominent LDs were observed. In addition, this study proved that LDs were formed during stationary-phase of growth. Furthermore, this study confirmed apparent indifference to carbon sources such as glucose vs glycerol on LDs formation. However, addition of exogenous fatty acids (oleic or palmitic) promoted the formation of LD, confirming the decisive role of fatty acids for $M t b$ energy systems and structural carbon sources. Further analysis identified the chemical composition of LD in M. smegmatis. For this, the non-polar lipids were extracted and analyzed using thin layer chromatography, Proton $\mathrm{Nu}$ clear Magnetic Resonance (NMR) and gas chromatography-mass spectrometry (GC-MS). The results showed that TAG was the principal component. Extending the M. smegmatis research above into pathogenic $M t b$ isolated from TB patients' sputa confirmed the presence of LD in $M t b$ from sputum, and from stationary phase of cultured Mtb [29]. LD synthesis pathway analysis showed that TAG might be imported 
directly from macrophages or synthesized de novo [12, 13]. For a detailed understanding of LD nucleation, readers are advised to refer to excellent reviews elsewhere [34-36].

\section{Lipid droplets in macrophage and $M t b$ evolutionary arms race}

$M t b$ can exist extracellularly in the granuloma microenvironments, or in the cytoplasm or phagosome of (foamy) macrophages (FM). Several hypotheses have been proposed regarding the survival strategies of $M t b$ inside the acidic phagosome of macrophage [37]. From these, the majority of studies support the view that $M t b$ survives inside the hostile phagosome environment by avoiding the fusion of lysosome with phagosome [3841]. Briefly, $M t b$ avoids phagolysosome amalgamation through retaining immature phagosome markers (Rab5, Rab11 and Coronin1/TACO) and blocking the recruitment of mature endosome markers (Rab7, CD63 and Cathepsin D) at phagosome surfaces [37].

A second view suggests that phagolysosome fusion occurs, but that $M t b$ resides inside the hostile phagosome environment through upregulation of serine proteases such as Mycobacterial acid resistance Protease (MarP) [42]. MarP is an acid tolerance and virulence factor. The seminal experiment was carried out by Botella et al. (2017) to differentiate whether $M t b$ survival is via acid tolerance or phagolysosome fusion avoidance. To resolve this issue, two transposon mutants were prepared; marP::Tn (acid susceptible) and ptpA::Tn ( $\uparrow$ lysosomal trafficking for enhancing lysosomal action). The study confirmed that, marP::Tn mutants became hypersusceptible to lysosomal content and growth attenuation occurred. Furthermore, 25 times higher attenuation rate was observed among marP::Tn (acid susceptibility) than ptpA::Tn (phagolysosome fusion) mutants. This showed that lysosomal acid tolerance was a more significant determinant than avoidance of phagosome-lysosome fusion [42]. Botella and colleagues further elaborated the mechanism of action of MarP. Accordingly, RipA, a peptidoglycan hydrolase is a substrate for MarP and acid tolerance is achieved when MarP cleaves RipA for its biological function [43].

The third hypothesis suggests that $M t b$ survives inside the phagosome through its interaction with host LD. Host LD helps $M t b$-phagosome evading the macrophage's defense systems [44]. In this survival pathway, the different $M t b$ cell wall components are participated. For instance, lipoarabinomannan (LAM) block endosome maturation and phosphatidylinositol mannosides (PIM) nourish the pathogen [44]. Additionally, the LucA protein from $M t b$ forms a complex with Mcel and Mce4 fatty acid transporters to scavenge cholesterol and fatty acids from the cytoplasm of the macrophage [45].
The conclusion is that two or more of these survival strategies are employed by $M t b$. Figure 2 below illustrates these $M t b$ survival strategies.

Whether macrophage LD formation is in favor of pathogen survival or part of the host defense is a subject of on-going debate. Some studies suggest that host LD gives an evolutionary advantage to the bacilli by serving as depot of chemical energy [28, 44, 48] and shelter [49, 50]. In Barisch et al (2017) review, host LD is found in close apposition to the $M t b$ phagosome, serving as a lipid supply for $M t b$ LD formation via fusion, coalescence or lipophagy-dependent internalization [48]. Peyron et al (2008) supported this hypothesis [51], showing that FM formation is a unique feature of pathogenic Mycobacteria (Mtb, M. avium) and oxygenated mycolic acid played a role in the differentiation of macrophages into FM. Peyron and colleagues infect macrophages with $M t b$ and scanned the formation of the granuloma at days 3 and 11 using electron microscopy. At 3-days after infection, $M t b$ was found only inside the phagosome or around the granuloma microenvironment but not inside the cytoplasm of FM. At 11-days post infection, the FM population increased from $9 \%$ (day $^{-3}$ post infection) to $41 \%$, the size of LD of FM were also increased (>5 LD/FM), and 1-20 phagocytosed $M t b$ were observed. While $60 \%$ of phagosomes were evenly distributed in the cytoplasm of FM, nearly $21 \%$ of phagosomes were stationed in close proximity to the FM-LD and progressive engulfment was observed. This study also noted that only $M t b$ that transferred from the phagosome to FM-LD became LD positive, thereby proposing that $M t b$ LD may be derived from FM-LD [51]. According to Daniel et al. (2011), hypoxia is also another key factor for macrophage LD formation, where host LD in the form of TAG were incorporated into $M t b$ LD [28]. Taken together, these studies support the view that, host and Mtb LDs benefit the evolutionary success of the pathogen.

In apparent contradiction to the above research, a study by Knight et al. (2017) suggested that host LD formation is entirely dependent on IFN- $\gamma /$ HIF- $1 \alpha$ activation and few LDs are observed without these cytokines. For instance, when primary murine bone marrow derived macrophages were infected with $M t b$, very few, (average of $<1$ ) LD were formed by macrophages. However, a large number of LD (average of $>10 \mathrm{LDs} /$ macrophage) were formed when these $M t b$-infected macrophages were treated with IFN- $\gamma ; 100 \%$ of macrophages accumulated LD. Additionally, the authors showed that $M t b$ can extricate different types of lipid from the host. Knight et al. concluded that $M t b \mathrm{LD}$ and host LD formation are two opposing and uncoupled phenomena; where $M t b$ LD are synthesized as means of $M t b$ survival, whereas 


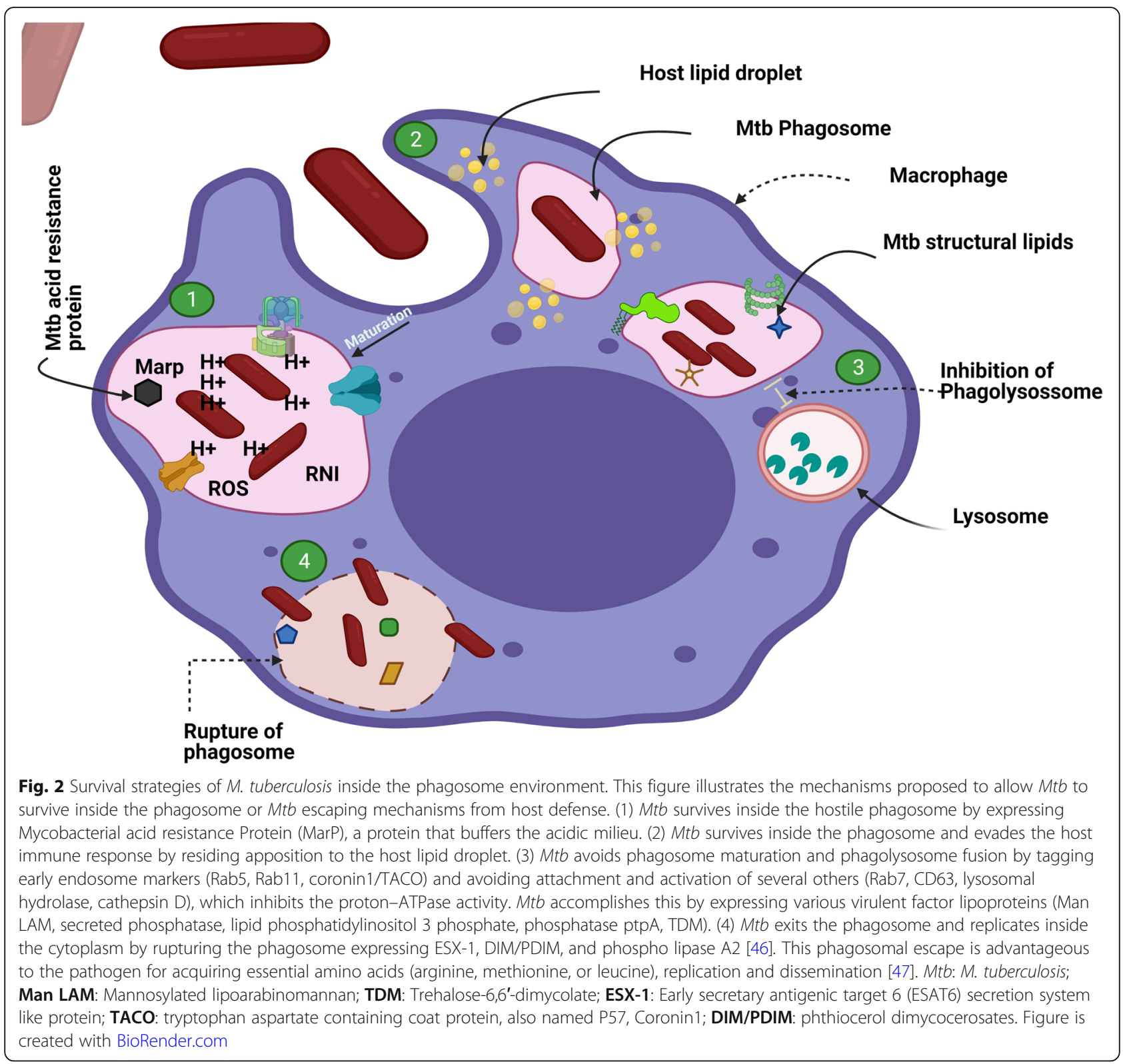

host LD synthesis is a mechanism of host defense [52]. Other studies have also reported that the accumulation of LD in the macrophage cytoplasm is part of a coordinated host defense mechanism [52-54].

The up-regulation of $M t b$ genes ( $h s p X, i c l 1, \operatorname{tgs} 1, \operatorname{dos} R$, lipY, $p c k A$ ) related to LD metabolism and hypoxia in the granuloma and inside the phagosome environment confirmed the rescue function of $M t b$-LD [55]. Taken together, the evidence supports the view that $M t b \mathrm{LD}$ formation serves the pathogen, and may act as a source of chemical energy [12, 56], shelter of genomic DNA [50], scavenger of toxic free fatty acids [12], creating non-mutational phenotypic heterogeneity [7] such as formation of antibiotic tolerance [55, 57-59] and evading host immune cells by hiding its pathogen associated molecular patterns (PAMP) [60, 61]. The host LD and the $M t b$ cell wall lipid components are also essential for $M t b$ survival by avoiding autophagy and delaying lysosomal trafficking towards the phagosome $[62,63]$.

\section{Clinical relevance of $M$. tuberculosis lipid droplets Dynamics and role of LD positive Mtb during TB treatment}

Sloan et al 2015 hypothesized that the proportion of LDpositive $M t b$ in sputum influences the outcome of TB treatment. To address this, sputum culture and Auramine-LipidTox staining of sputum smears were carried out on consecutively collected samples through the treatment period and the treatment outcome was recorded as good or bad [64]. The study found a higher 
proportion of LD-positive $M t b$ among patients with poor treatment outcome [64]. Kayigire et al (2015) assessed the dynamics of LD positive $M t b$ in sputum over treatment period. The study identified three types of $M t b$ in TB patients; vegetative cells that stained positively with Auramine-O (green), LD-positive Nile-red stained $M t b$ (red) and Mtb cells stained by both (cream cells; that were borderline between the two), whose relative proportions changed over the course of treatment. Prior to the start of anti-TB treatment, green cells predominate and LD-positive cells (red) shared a small proportion of all $M t b$. As treatment proceeded, there was a clear shift towards fewer replicating/green $M t b$ cells and more borderline and red LD-positive cells [65]. Taken together, these data suggested the value of LD staining techniques for monitoring treatment outcomes. Since LD-positive $M t b$ appear to be drug-tolerant (or drug-resistant) and refractory to staining with Auramine $\mathrm{O}$, techniques targeting these phenotypes might have higher resolution and become a sensitive biomarker for treatment monitoring and predicting treatment outcome. Moreover, such studies may combine with drug discovery programs that target drug-tolerant populations of $M t b$ [66-68].

\section{The role of $M t b$-LD in TB transmission}

The role of $\mathrm{LD}$ in $M t b$ transmission is a controversial issue that warrants further scrutiny $[29,69]$. Jones-López and colleagues determined the variation in $M t b$ transmission from infected households to their close contacts. The finding showed significant heterogeneity of $M t b$ transmission among human living together in a single household. This study classified isolates into $M t b$ high transmission $(M t b-\mathrm{HT})$ and $M t b$ low transmission $(M t b-$ LT) strains [69]. According to this study, $M t b$-LT isolates showed an increased LD accumulation than $M t b$ HT isolates. Moreover, in Animal model study by Verma et al, $M t b$-LT isolates showed high growth rate. Furthermore, diffused inflammatory lung pathology, high CD8+ $\mathrm{T}$ cells, high inflammatory response and high mortality rate were observed among TB patients infected with $M t b$-LT isolates. On the contrary, well defined circumscribed lesions, high degree of granuloma, caseous necrosis, cavitary lesion and high transmission rate were found among patients infected with $M t b-\mathrm{HT}$ isolates. Hence, this study suggest that the presence of LD per se does not confer a specific transmission fitness and transmission phenotype [70], a result in contrast with the Garton et al study [29]. Collectively, TB transmission rate is deduced to be driven by several factors and TB transmission study should consider clinical presentation, host immunity, pathogen and environmental axis. Since sputum derived $M t b$ are phenotypically and metabolically heterogeneous, which phenotypes (containing differing proportions of LD positive $M t b$, LD negative, border line or all types) are more transmissible is unknown and further study is required.

\section{LD-positive Mtb in pulmonary and extra pulmonary TB}

Little is known about the relationship between $M t b$-LD formation and clinical manifestation of disease as pulmonary TB (PTB) versus extra-pulmonary TB (EPTB). Lung is the primary site of TB disease initiation and lymph node is the primary site of adaptive immune initiation. Initiation of an adaptive immune response to $M t b$ depends on the transport of live bacteria from the lung to the mediastinal lymph nodes, and delay of this process may be advantageous for the pathogen [71]. Ganchua et al (2018) suggested that the lymph node (LN) provides an ecological niche for $M t b$, based on evidence of higher survival of $M t b$ in the LN than in lung granuloma. This may be because granulomas that form in LNs lack B cell-rich tertiary lymphoid structures. With this, LNs are not only sites of antigen presentation and immune activation during infection, but also a niche that is protected from adaptive immune-mediated responses [72]. Severe diseases like EPTB is the outcome of a co-evolutionary mismatch [73]. The pathogen's fitness depends on its ability to cause a high level of damage to its human host [73, 74]. Little is known about relative proportions of $\mathrm{LD}$-positive $M t b$ in pulmonary parenchymal and lymph node tissue. In this regard, Maji and colleagues analyzed the transcriptome of tubercular lymphadenitis tissue and observed downregulation of host lipid metabolism related genes, in contrast to pulmonary tissue. This study confirmed the differential expression of lipid metabolic signatures between TB lymphadenitis and PTB [75]. However, the $M t b-\mathrm{LD}$ related transcriptome and the proportion of $\mathrm{LD}$ positive $M t b$ among PTB and EPTB was not determined. The observation of a shift from predominant pulmonary $\mathrm{TB}$ to predominant $\mathrm{LN}$-associated TB in certain geographic regions like Ethiopia, is provocative. The link between $M t b$ lineages and type of TB (PTB Vs EPTB) is unclear $[76,77]$ and some association between Mycobacterium africanum (MAF) and EPTB [78-80] have been reported. In general, LD formation profiling among $M t b$ and MAF isolates disaggregated by types of TB (EPTB Vs PTB) might narrow the existing knowledge gap.

\section{Lipid droplets formation and $M t b$ lineages}

The Beijing lineage (lineage 2) of $M t b$ appears to be the slowest in time to culture conversion after the start of anti-TB treatment [81]. A study comparing the phenolic glycolipid (PGL), TAG and dosR regulon of Beijing lineages with lineage 3 and lineage 4 showed striking variation among lineages [82]. Briefly, while 10, 60 and $80 \%$ isolates under Beijing lineages (groups 3,4 and 5 
respectively) contain PGL, other strains from Beijing and non-Beijing lineages did not produce PGL. Additionally, while all the 36 isolates from Beijing lineages included in the analysis produced TAG, the 18 non-Beijing lineages included in the analysis failed to synthesize detectable amounts of TAG during in vitro aerobic culture [82]. However, while the authors reported 100\% TAG production in Beijing lineage (L2 strains), they reported no accumulation of TAG in L3 and L4 Mtb isolates, a result that seems very unlikely. The culture conditions might be one factor leading to this discrepancy.

Diarra et al (2018) conducted a prospective cohort study to determine whether M. africanum (MAF, L6) responds faster to TB treatment more quickly than $M t b$ L4, using Auramine $\mathrm{O}$ and Fluorescein Diacetate (FDA) viability stains. The authors found that MAF responded better to TB treatment but time kill kinetics was slower for MAF than L4 [81]. One would predict that slow smear conversion might lead to more transmission and drug resistance, however, based on clustering and drug resistance data, rates of transmission and drug resistance were not higher for MAF compared with $M t b$ [83, 84]. The link between poor treatment outcome, drug tolerance and LDs is well explained elsewhere [28, 64, 65]. The slow growth rate $[79,81,85]$ and slow clinical recovery rate associated with MAF strains among TB cases has also been reported elsewhere [86]. Similar to MAF, $M t b$ lineage 7 , which is restricted to Ethiopia and the Horn of Africa, grew more slowly in vitro and produced smaller colonies on solid media [87] in comparison to other $M t b$ strains. It is not known whether any of these characteristics correlate with LD. Collectively, the propensity of Mtb LD formation among lineages is known and a simple LD comparative analysis might provide insight regarding the differential LD formation among $M t b$ lineages.

\section{The proportion of LD-positive Mtb in sputum}

The clinical relevance of LD-positive $M t b$ bacilli in sputum was first elucidated by Garton and colleagues [29, 88]. These studies concluded that the proportion of LDpositive $M t b$ in sputum lies between 3 and 86\%, with 2$8 \mathrm{LDs} /$ bacilli [29]. Growth rate is significantly associated with the proportion of LD-positive $M t b$ bacilli in sputum [29]. Garton and colleagues concluded that the replicating phenotypes of $M t b$ in sputum were a minor component, and LD-positive $M t b$ bacilli were predominant. This report contrasted with that of the cell culture study by Daniel et al [28]. Daniel et al characterized dynamic of $M t b$ LD formation inside the hypoxic FMs incubated under $1 \% \mathrm{O}_{2}$ After 0,3 , and 5 days of incubation from this hypoxic state, $M t b$ recovered from FMs were stained with dual Auramine-O and Nile red staining techniques. It was found that the fraction of the $M t b$ population positive for Auramine O staining decreased from 86\% at day- 0 to $\sim 40 \%$ at day-5, while Nile Red-positive LDpositive cells increased with time from $\sim 35 \%$ prior to hypoxic treatment to $\sim 81 \%$ at day-5 of $1 \% \mathrm{O}_{2}$ (hypoxia) treatment, more than two-fold increment [28]. Taken together, studies which could determine the Mtb population (LD positive, LD negative, borderline) dynamic is desirable.

\section{Transcriptome profile of $M$. tuberculosis from patient sputa}

The spectrum of $M t b$ metabolic reprogramming is better studied through transcriptome profiling. This is because the transcriptome of sputum-derived $M t b$ provides genome-wide information on the real time metabolic state of $M t b$ populations. In addition, the state of $M t b$ metabolic reprogramming is more readily ascertained from transcriptome data than from genomic data, through quantifying the changing expression levels of $M t b$ transcripts in distinct physiological conditions. Hence, evidences on this subtopic are synthesized from the transcriptome of sputum-derived $M t b$ in comparison with the transcriptomes of $M t b$ grown in vitro culture and over the course of TB treatment. This section reviewed only original articles and the methodology of the studies are summarized in Table 1.

The key findings of the individual studies referred in Tables 2. The transcriptome data showed distinct transcriptome profiles which might be explained by differences in the technique, study populations and number of genes targeted. The sputum-derived $M t b$ transcriptome relatively mirrored the lung/ broncho alveolar lavage (BAL) derived $M t b$ transcript profile. The slight differences between the two (sputum and BAL) might be due to the higher hypoxic state of the lung than upper respiratory tracts such as bronchi and oral cavity. Hence, sputum $M t b$ transcriptome profiling might be a substitute for the BAL transcriptome for assessing Mtb pathogenesis and treatment conditions [93]. Comparing the $M t b$ transcriptome in lipid and dextrose rich medium did not showed significant differential expression [60]. The sputum-derived $M t b$ transcriptome is quite different from exponentially growing $M t b$ in animal models and in-vitro.

Relative to pretreatment expression, the mRNA abundance decreased by $50 \%$ over $12 \mathrm{~h}$ during the first 2 days of anti-TB treatments shots [94]. Over the course of anti-TB treatment, genes encoding drug activating enzymes such as a catalase peroxidase $(\mathrm{kat} G)$, nicotinamidase/pyrazinamidase $(p n c A)$, and Ethionamide activator (eth $A$ ) showed repression, indicating that majority of the $M t b$ populations are dying and entered into drug related stress tolerance state [94]. Genes related to persister phenotypes such as triacylglycerol synthases and, ATP- 
Table 1 Transcriptome profiling and validation techniques used for Mtb sputum transcriptomics

\begin{tabular}{|c|c|c|c|c|}
\hline Comparative transcriptomics of SMtb & RNA profiling method & Validation & \#Transcript & Reference \\
\hline SMtb vs culture with 7H10 agar /7H9 broth/Dubos ${ }^{a}$ & Microarray & qRT-PCR & 516 & {$[29]$} \\
\hline SMtb vs culture & Microarray & qRT-PCR & 557 & [89] \\
\hline SMtb vs MAF/Mtb & qRT-PCR & & 2179 & [90] \\
\hline SMtb vs Exponential phase of liquid culture & Dual RNA seq & Nano String & 198 & [91] \\
\hline SMtb vs Stationary phase of liquid culture & Dual RNA seq & Nano String & 392 & [91] \\
\hline Sputum vs MGIT 460 culture & Microarray & qRT-PCR & 1083 & [92] \\
\hline SMtb at Day 3 vs SMtb at day0 treatment & Microarray & qRT-PCR & 109 & [92] \\
\hline SMtb at Day $7 / 14$ vs day 0 treatment & Microarray & qRT-PCR & 39 & [92] \\
\hline Lipid rich Dubos broth ${ }^{\mathrm{b}}$ vs Dextrose rich Dubos broth ${ }^{\mathrm{b}}$ & RNA seq & qRT-PCR & - & {$[60]$} \\
\hline SMtb/ BAL-Mtb vs 7H9/ DTA ${ }^{c}$ culture & qRT-PCR & & - & [93] \\
\hline SMtb before Rx vs SMtb after Rx & qRT-PCR & qRT-PCR & 2411 & [94] \\
\hline Sputum Mtb vS culture H37Rv & Microarray & qRT-PCR & - & [95] \\
\hline
\end{tabular}

${ }^{\mathrm{a}} 7 \mathrm{H} 10$ agar with oleic acid-albumin-dextrose-catalase supplement or in $7 \mathrm{H} 9$ broth with albumin-dextrose-catalase supplement, $0.2 \%$ glycerol and $0.05 \%$ Tween-80. Hypoxic (non-replicating persistence) cultures M. tuberculosis strains H37Rv and CH were grown in Dubos Tween albumin broth. ${ }^{b}$ Dubos broth (Difco), without glycerol, containing $0.5 \%$ albumin, supplemented with either $0.2 \%$ dextrose or a lipid mixture (oleic acid, palmitic acid, stearic acid, at final concentration of $0.001 \%$ each, plus $0.01 \%$ cholesterol). ${ }^{\mathrm{C}} 7 \mathrm{H} 9$ media (0.05\% Tween $80,0.2 \%$ glycerol, $10 \%$ ADC supplement)/ DTA: Dubos Tween albumin; for the NRP-2 model was grown in $100 \mathrm{~mL}$ Dubos Tween albumin (DTA). SMtb sputum-derived M. tuberculosis, Mtb Mycobacterium tuberculosis, vs versus, Rx treatment, MAF

Mycobacterium africanum, L4 Lineage 4, qRT-PCR Real-Time Quantitative Reverse Transcription PCR, RNA seq RNA-sequencing, DTA Dubos Tween, BAL Broncho alveolar lavage

binding cassette transporter and toxin molecules were induced [94].

In terms of energy utilization, the ATP synthase operon in sputum was downregulated and the transcriptome of sputum-derived $M t b$ was more similar to the transcriptome of $M t b$ during stationary phase growth than during exponential growth of $M t b$ in-vitro. Decrease in abundance of phoP and esx transcripts indicated a switch to lipolysis and decreased virulence [91]. PhoPR a two-component system is essential for virulence through its secretary function and its mutation leads to a loss of virulence [96]. Because the $M t b$ in sputum has originated from a granuloma rich in lipid, it is not unexpected that the transcriptome of sputum-derived $M t b$ microenvironment is enriched for transcripts involved in lipid metabolism [91, 92], microaerophilic respiration, low energy state, and persistence [29, 94].

The DosR regulon (dosR) which constitutes over 50 genes [4] is activated by low oxygen tension [97] and accumulation of oxygen byproducts such as $\mathrm{H}_{2} \mathrm{O}_{2}, \mathrm{CO}, \mathrm{NO}$, and ethanol [98]. The dos $R$ regulon is over expressed in sputum and during anti-TB treatment $[92,94]$ compared with $\log$ phase in vitro culture $[92,93]$. The expression of the dos $R$ regulon is likely a general indicator of bacteria's tolerance to oxygen and may have no direct role in LD metabolism. Hence, while expression of the $d o s R$ regulon is observed in both growing and persister populations of $M t b[29,99]$, its expression is dependent on the degree of the hypoxic state. Comparatively upregulation of $\operatorname{dos} R$ regulon was observed among Lineage $2 M t b$ than Lineage $4 M t b$ from sputum [91] and among Mtb-L4 than among MAF-L6 [90]. These results suggest that upregulation of the $\operatorname{dos} R$ regulon is an indicator of the aerophilic state of $M t b / \mathrm{MAF}$ rather than a marker of metabolic states linked to LD.

M. tuberculosis genes such as dosR regulon, hspX, $m p r A B$ and $P E / P P E$ and those involved in the glyoxylate shunt, methylcitrate cycle, cholesterol catabolism, nitrate reduction metabolism were upregulated relative to $\log$ phase control H37Rv cells grown in vitro [29, 89, 91, 92]. In contrast, the tricarboxylic acid (TCA) cycle, electron transport chain (ETC), polyketide synthase, ESX secretion apparatus, mycolic acid synthesis, NADH dehydrogenase and cytochrome c reductase were downregulated in sputum-derived $M t b$ compared to log phase aerobic in vitro culture [91, 92]. During treatment, downregulation of ESX secretion and anti-TB drug activating enzymes were noticed compared with pretreatment sputum $M t b$ [94]. When under extreme stress, NRP-2 state, anaerobic respiration and $\operatorname{dos} R$ were upregulated and genes involved in growth and metabolism were repressed [93] (Table 2). Garcia et al concluded that the transcriptomes of BAL and sputum-derived $M t b$ reflect a moderate level of hypoxia approximately midway on a spectrum of the hypoxic state between aerobic growth and NRP-2 [93]. En masse, the majority of genes from the information pathway, cell wall and cell processes, virulence, detoxification, adaptation, secretion, transport, intermediary metabolism and respiration [89] are repressed in $M t b$ from direct sputum.

Anti-TB treatment is typically monitored by microscopy and culture conversion. However, such techniques are inadequate for the detecting non-replicating drug-tolerant $M t b$, which is important for predicting treatment duration, treatment outcome and drug resistance. Techniques measuring 
Table 2 The summary of transcriptomes of M. tuberculosis in sputum versus other conditions, 2021

\begin{tabular}{|c|c|c|c|c|}
\hline $\begin{array}{l}\text { Transcriptome } \\
\text { condition }\end{array}$ & $\begin{array}{l}\text { In vitro } \\
\text { comparator }\end{array}$ & URG in sputum $M t b$ & DRG in sputum $M t b$ & Ref \\
\hline SMtb vs Culture & $\begin{array}{l}\text { 7H10 agar } \\
\text { /7H9 broth/ } \\
\text { Dubos }\end{array}$ & dosR, icl1, hspX, narK2, tgs 1, PE/PPE & nuoB, acrC, and ctaD & {$[29]$} \\
\hline SMtb Vs Culture & $\begin{array}{l}\text { No } \\
\text { information }\end{array}$ & Conserved Hypotheticals. mprAB: dos $R$ is stable & $\begin{array}{l}\text { pks 15/1, pks10 } \\
\text { Pks12, phoP, ESX 1-ESX-5 }\end{array}$ & {$[89]$} \\
\hline SMtb Vs Culture & $\begin{array}{l}\text { Liquid } \\
\text { culture }\end{array}$ & $\begin{array}{l}\text { ACOD1/IRG1, GLUT1, MCT4, ESX-3, Rv0106, Rv2990c, } \\
\text { ESX-3, mprA }\end{array}$ & $\begin{array}{l}\text { TCA cycle, ETC, NADH dehydrogenase, pentose } \\
\text { phosphate pathway (PPP), NAPDH, ROS. PhoP, small } \\
\text { RNA mcr7, pks } 12 \text {, esat- } 6 \text { and } c f p-10, \text { phoP }\end{array}$ & {$[91]$} \\
\hline SMtb Vs Culture & MGIT 460 & $\begin{array}{l}\text { Glyoxylate shunt, methylcitrate cycle (icl, prpC and } \\
\text { rv1129c), catabolism of cholesterol and fatty acids, and } \\
\text { tgs; Nitrate reduction (nark2/3). dosR nrdZ, nark2, } \\
\text { rv1738, pfkB, hspX, hrp 1,rv3126c and rv3128c }\end{array}$ & 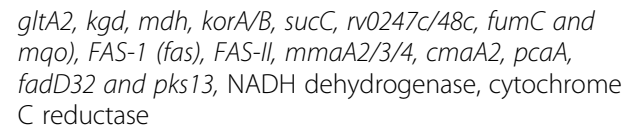 & {$[92]$} \\
\hline SMtb Vs culture & 7H9/ DTA ${ }^{c}$ & $\begin{array}{l}\text { sputum and BAL had significant up-regulation of the } \\
\text { dosR regulon }\end{array}$ & Ribosomal genes and primary metabolism genes & [93] \\
\hline $\begin{array}{l}\text { Day } 7-14 \text { days } \\
\text { Vs day } 0\end{array}$ & $\begin{array}{l}\text { None } \\
\text { applicable }\end{array}$ & $\begin{array}{l}\text { Anaerobic respiration, } P E / P P E \text { genes, is, } \\
\text { dosR,transcriptional factors, oxidative stress, sigma } \\
\text { factors, toxin-antitoxin modules, }\end{array}$ & $\begin{array}{l}\text { TCA cycle, ATP synthesis, ribosomal proteins, pks, ESX, } \\
\text { replication, efflux pumps, drug-activating enzymes \& } \\
\text { drug targets }\end{array}$ & {$[94]$} \\
\hline $\begin{array}{l}\text { SMtb at day } 3 / \\
7 / 14 \text { Vs day } 0 \\
\text { Rx }\end{array}$ & $\begin{array}{l}\text { None } \\
\text { applicable }\end{array}$ & $\begin{array}{l}\text { Mtb responses at } 7 \text { and } 14 \text { daysduring chemotherapy } \\
\text { were most similar to that of bacillibefore drug therapy } \\
\text { had begun }\end{array}$ & methylcitrate & {$[92]$} \\
\hline Day 14 Vs day2 & $\begin{array}{l}\text { None } \\
\text { applicable }\end{array}$ & $\begin{array}{l}\text { tgs, and ATP-binding cassette transporter and toxin. } \\
\text { Rv } 1258 c \text {, bacA, and mmr, rpoB. TA modules, sigma } \\
\text { factors }\end{array}$ & $\begin{array}{l}\text { ESX and ribosomal genes, drug-activating enzymes } \\
\text { katG, pncA, and ethA, gyrase, bedaquiline target atpE }\end{array}$ & {$[94]$} \\
\hline BAL vs sputum & 7H9/ DTA & $\begin{array}{l}\text { dos } R \text { regulon expression was higher in BAL than in } \\
\text { sputum }\end{array}$ & BAL had lower expression of ribosome proteins & [93] \\
\hline $\begin{array}{l}\text { Lipid-NRP1 Vs } \\
\text { Dextrose-NRP1 }\end{array}$ & $\begin{array}{l}\text { Dubos } \\
\text { broth }^{\text {b }}\end{array}$ & $\begin{array}{l}\text { Higher virulence, detoxification \& adaptation, lipid } \\
\text { metabolism, intermediary metabolism\& respiration, } \\
\text { regulatory protein }\end{array}$ & Insertion sequences \& phages & {$[60]$} \\
\hline In NRP-2 state & 7H9/ DTA & $\begin{array}{l}\text { dos } R \text { regulon, oxidative stress responses, anaerobic } \\
\text { respiration }\end{array}$ & Growth and metabolism & [93] \\
\hline \multicolumn{5}{|c|}{ 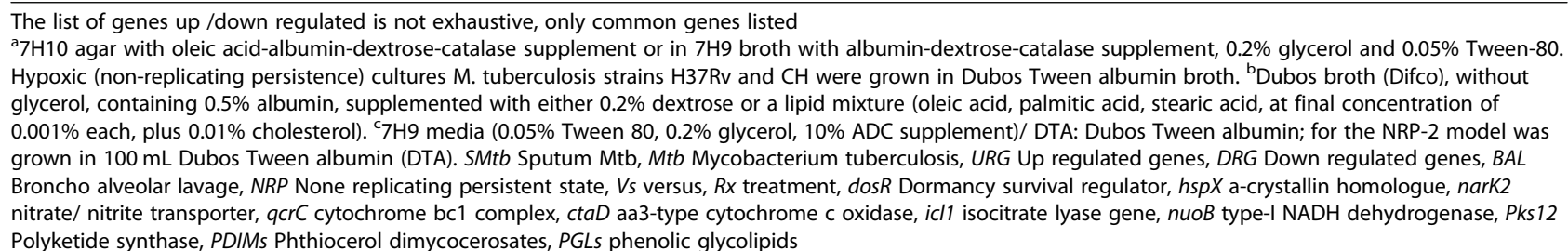 } \\
\hline
\end{tabular}

$16 \mathrm{~s}$ rRNA or pre-rRNA promise to add new depth to our understanding of the efficacy of drug combinations in patients $[100,101]$. Demirci and colleagues assessed the diagnostic accuracy of $M t b$-mRNA-based RT-qPCR technique, with the BACTEC MGIT 960 method used as the gold standard. The findings were encouraging, in that the mRNA-based method appeared to be more sensitive and specific than other methods [102]. However, additional information is needed before this technique can be translated into clinical practice. In particular, questions with regard to $M t b$ persistence and dormancy need to be addressed and defined [12, 29, 103-105].

\section{Study strength and limitations}

This review summarized pertinent information regarding the role of $M t b \mathrm{LD}$ on host-pathogen interactions, diagnosis, treatment and transmission. As such, the review highlighted conflicting reports and advised future research areas. However, our literature search strategy is not complete and the quality of included articles were not appraised.

\section{Conclusions}

The role of LD in the co-evolutionary arms race, granuloma formation, and treatment outcome of TB must be recognized. The power of $\mathrm{LD}$ in determining the distinct metabolic, physiological, phenotypic state from sputumderived $M t b$ is described. The presence of $\mathrm{LD}$ is observed universally in prokaryotes including $M t b$. However, LD are more common and more abundant: 1) in BAL-derived $M t b$ than in sputum-derived $M t b, 2)$ after 
anti-TB drug therapy, and 3) during stationary phase than exponential phase of growth in vitro culture.

LD are a source of chemical energy and phenotypic heterogeneity. They can also delay lysosomal trafficking towards phagosomes, block autophagy, promote immune cell evasion and scavenge toxic metabolites and signaling. The influence of LD on transmissibility and virulence of $M t b$ is less well understood. Multiple factors from the pathogen, host and environment axis might influence $M t b$ transmission, however some evidence links overproduction of LD in the $M t b$ Beijing lineage 2 and some $M t b$ lineage 4 isolates with higher transmissibility/ virulence.

Several different transcriptome profiles were detected in LD-positive $M t b$, which could reflect sample-tosample variation, differences in methodology or other experimental conditions. Nevertheless, we conclude that $M t b$ in sputum exists in a variable phenotypic and metabolic states. The dynamics of gene expression in LDpositive $M t b$ from sputum provides clinically-important information on the evolution and pathogenicity of $M t b$. Further studies are needed to investigate the relationships between intracellular LDs and $M t b$ lineages, $M t b$ transmission capacity, clinical phenotype and $M t b$ pathophysiology.

Transcriptomic analysis of sputum-derived LDpositive $M t b$ cells could prove to be useful in clinical and research settings. For instance, lipophilic staining targeting LD-positive $M t b$ might be more sensitive and specific than current methods, such as ZN/ FM microscopy, which only detects actively growing $M t b$. Finally, lipid metabolism-associated genes are upregulated in LD-positive $M t b$. Based on this observation, it may be possible to develop an mRNA based diagnostic test that is sensitive and specific for the detection of LD-positive $M t b$. Such a test could be valuable for TB diagnostics and to monitor treatment of TB. This exciting possibility will be explored in future research.

\footnotetext{
Abbreviations

BAL: Broncho alveolar lavage; CE: Cholesterol ester; DIM/PDIM: Phthiocerol dimycocerosates.; DTA: Dubos Tween; EPTB: Extra-pulmonary TB; ESAT6: Early secretary antigenic target 6; ESX-1: ESAT6 secretion system like protein; ETC: Electron transport chain; FDA: Fluorescein Diacetate; FM: Foamy Macrophages; GC-MS: Gas chromatography-mass spectrometry; ILI: Intracellular lipid inclusions; L4: Lineage 4; LAM: Lipoarabinomannan; LB: Lipid body; LD: Lipid droplet; LDs: Lipid droplets; LN: Lymph node; MAF: Mycobacterium africanum; MAF: Mycobacterium africanum; Man LAM: Mannosylated lipoarabinomannan; MarP: Mycobacterial acid resistance Protease; Mtb: Mycobacterium tuberculosis; MTBC: Mycobacterium tuberculosis complex; NMR: Proton Nuclear Magnetic Resonance; OB: Oil body; PC: Phosphatidylcholine; PE: Phosphatidylethanolamine; PGL: Phenolic glycolipid; PI: Phosphatidylinositol; PIM: Phosphatidylinositol mannosides; PTB: Pulmonary TB; qRT-PCR: Real-Time Quantitative Reverse Transcription $P C R_{i ;}$ RNA seq: RNA-sequencing; Rx: Treatment; SMtb: Sputum-derived M. tuberculosis; TACO: Tryptophan aspartate containing coat protein; TAG: Triacylglycerol; TB: Tuberculosis; TCA: Tricarboxylic acid cycle; TDM: Trehalose-6,6'-dimycolate; vs: versus; YB: Youmans' broth
}

\section{Acknowledgements}

The authors would like to thank Institute of Biotechnology staffs for their encouragement and support during the review process. The review is part of a mega project funded by Institute of Biotechnology, Bahir Dar

University under the project PI of Endalkachew Nibret.

\section{Authors' contributions}

DM: Conceived the review topic, did the literature search, and drafted the manuscript; AD, AM, SAY, TT EN, AM: contributed to writing and editing, BA, SJW, AA: helped conceive the study topic, and edit the review. All authors read and approved the final manuscript.

\section{Funding}

This research received no specific grant from any funding agency.

\section{Availability of data and materials}

All data generated or analyzed during this study are included in this published article.

\section{Declarations}

Ethics approval and consent to participate

Not applicable.

\section{Consent for publication}

Not applicable.

\section{Competing interests}

The authors declare that they have no competing interests.

\section{Author details}

'Department of Medical Microbiology, College of Medicine and Health Sciences, Bahir Dar University, Bahir Dar, Ethiopia. ${ }^{2}$ Institute of Biotechnology, Bahir Dar University, Bahir Dar, Ethiopia. ${ }^{3}$ The Centre for Innovative Drug Development and Therapeutic Trials for Africa (CDT-Africa), Addis Ababa University, Addis Ababa, Ethiopia. ${ }^{4}$ Armauer Hansen Research Institute, Jimma Road, ALERT Compound, PO Box 1005, Addis Ababa, Ethiopia. ${ }^{5}$ Department of Medical Microbiology, Immunology and Parasitology, College of Medicine and Health Sciences, Addis Ababa University, Addis Ababa, Ethiopia. ${ }^{6}$ Department of Microbiology, University of Oslo, PO Box 1071, Blindern, NO-0316 Oslo, Norway. ${ }^{7}$ Coalition for Epidemic Preparedness Innovations, CEPI, P.O. Box 123, Torshov, 0412 Oslo, Norway. ${ }^{8}$ Department of Microbiology, Oslo University Hospital, PO Box 4950, Nydalen, NO-0424 Oslo, Norway. ${ }^{9}$ Department of Medical Microbiology, School of Biomedical and Laboratory Sciences, College of Medicine and Health Sciences, University of Gondar, Gondar, Ethiopia. ${ }^{10}$ Department of Biology, Bahir Dar University, Bahir Dar, Ethiopia. " Department of Global Health and Infection, Brighton and Sussex Medical School, University of Sussex, Brighton BN1 9PX, UK.

Received: 22 June 2021 Accepted: 9 September 2021

Published online: 03 October 2021

\section{References}

1. Gagneux S. Ecology and evolution of Mycobacterium tuberculosis. Nat Rev Microbiol. 2018;16(4):202-13. https://doi.org/10.1038/nrmicro.2018.8.

2. Gengenbacher M, Kaufmann SH. Mycobacterium tuberculosis: success through dormancy. FEMS Microbio Rev. 2012;36(3):514-32. https://doi.org/1 0.1111/j.1574-6976.2012.00331.x.

3. Fieweger RA, Wilburn KM, VanderVen BC. Comparing the metabolic capabilities of bacteria in the Mycobacterium tuberculosis complex. Microorganisms. 2019;7(6):177. https://doi.org/10.3390/microorganisms70601 77.

4. Cohen A, Mathiasen VD, Schön T, Wejse C. The global prevalence of latent tuberculosis: a systematic review and meta-analysis. Eur Respir J. 2019;54(3). https://doi.org/10.1183/13993003.00655-2019.

5. Neyrolles $\mathrm{O}$, Hernández-Pando R, Pietri-Rouxel F, Fornès P, Tailleux L, Payán $J A B$, et al. Is adipose tissue a place for Mycobacterium tuberculosis persistence? PLoS One. 2006;1(1):e43. https://doi.org/10.1371/journal.pone. 0000043.

6. WHO: Global tuberculosis report 2020. In: Global tuberculosis report 2020. Edited by WHO. Geneva: WHO; 2020. 
7. Dhar N, Mckinney J, Manina G. Phenotypic heterogeneity in Mycobacterium tuberculosis. Microbiol Spectrum. 2016;4(6):671-97. https://doi.org/10.1128/ microbiolspec.TBTB2-0021-2016.

8. Brown HA, Marnett LJ. Introduction to lipid biochemistry, metabolism, and signaling. Chem Rev. 2011;111(10):4-5820. https://doi.org/10.1021/ cr200363s.

9. Fahy E, Subramaniam S, Brown HA, Glass CK, Merrill AH Jr, Murphy RC, et al. A comprehensive classification system for lipids. Eur J Lipid Sci Technol. 2005;107(5):337-64. https://doi.org/10.1002/ejlt.200405001.

10. Singh P, Rameshwaram NR, Ghosh S, Mukhopadhyay S. Cell envelope lipids in the pathophysiology of Mycobacterium tuberculosis. Future Microbiol. 2018;13(06):689-710. https://doi.org/10.2217/fmb-2017-0135.

11. Ghazaei C. Mycobacterium tuberculosis and lipids: insights into molecular mechanisms from persistence to virulence. J Res Med Sci. 2018;23(1):63. https://doi.org/10.4103/jrms.JRMS_904_17.

12. Maurya RK, Bharti S, Krishnan MY. Triacylglycerols: Fuelling the hibernating mycobacterium tuberculosis. Front Cell Infect Microbiol. 2019;8:450.

13. Wilburn KM, Fieweger RA, VanderVen BC. Cholesterol and fatty acids grease the wheels of Mycobacterium tuberculosis pathogenesis. Pathog Dis. 2018; 76(2). https://doi.org/10.1093/femspd/fty021.

14. Chiaradia L, Lefebvre C, Parra J, Marcoux J, Burlet-Schiltz O, Etienne G, et al. Dissecting the mycobacterial cell envelope and defining the composition of the native mycomembrane. Sci Rep. 2017;7(1):1-12. https://doi.org/10.1038/ s41598-017-12718-4

15. Russell DG, VanderVen BC, Lee W, Abramovitch RB. Kim M-j, Homolka S et al: Mycobacterium tuberculosis wears what it eats. Cell Host Microbe. 2010;8(1):68-76. https://doi.org/10.1016/j.chom.2010.06.002.

16. Pal R, Hameed $S$, Kumar $P$, Singh S, Fatima Z. Comparative lipidomics of drug sensitive and resistant Mycobacterium tuberculosis reveals altered lipid imprints. 3 Biotech. 2017;7(5):1-10.

17. Ernst JD. The immunological life cycle of tuberculosis. Nat Rev Immunol. 2012;12(8):581-91. https://doi.org/10.1038/nri3259.

18. Beller M, Herker E, Füllekrug J. Grease on-perspectives in lipid droplet biology. Semin Cell Dev Biol. 2020;108:94-101. https://doi.org/10.1016/j. semcdb.2020.06.017.

19. Walther TC, Farese RV Jr. The life of lipid droplets. Biochim Biophys Acta. 2009;1791(6):459-66. https://doi.org/10.1016/j.bbalip.2008.10.009.

20. Zhang C, Liu P. The lipid droplet: a conserved cellular organelle. Protein Cell. 2017:8(11):796-800. https://doi.org/10.1007/s13238-017-0467-6.

21. Chi X, Ogunsade OO, Zhou Z, Li Z, Li X, Zhang M, et al. Lipid droplet is an ancient and inheritable organelle in bacteria. bioRxiv. 2020. https://doi.org/1 0.1101/2020.05.18.103093.

22. Herker E, Ott M. Emerging role of lipid droplets in host/pathogen interactions. J Biol Chem. 2012;287(4):2280-7. https://doi.org/10.1074/jbc R111.300202.

23. Lundquist PK, Shivaiah K-K, Espinoza-Corral R. Lipid droplets throughout the evolutionary tree. Prog Lipid Res. 2020:101029. https://doi.org/10.1016/j. plipres.2020.101029.

24. Pagán AJ, Ramakrishnan $L$. The formation and function of granulomas. Annu Rev Immunol. 2018;36(1):639-65. https://doi.org/10.1146/annurevimmunol-032712-100022.

25. Ehlers S, Schaible UE. The granuloma in tuberculosis: dynamics of a hostpathogen collusion. Front Immunol. 2013;3:411.

26. Thiam AR, Farese RV Jr, Walther TC. The biophysics and cell biology of lipid droplets. Nat Rev Mol Cell Biol. 2013;14(12):775-86. https://doi.org/10.1038/ nrm3699.

27. Farese RV, Walther TC. Lipid droplets finally get a little R-E-S-P-E-C-T. Cell. 2009;139(5):855-60. https://doi.org/10.1016/j.cell.2009.11.005.

28. Daniel J, Maamar H, Deb C, Sirakova TD, Kolattukudy PE. Mycobacterium tuberculosis uses host triacylglycerol to accumulate lipid droplets and acquires a dormancy-like phenotype in lipid-loaded macrophages. PLoS Pathog. 2011;7(6). https://doi.org/10.1371/journal.ppat.1002093.

29. Garton NJ, Waddell SJ, Sherratt AL, Lee SM, Smith RJ, Senner C, et al. Cytological and transcript analyses reveal fat and lazy persister-like bacilli in tuberculous sputum. PLoS Med. 2008;5(4):0634-45. https://doi.org/10.1371/ journal.pmed.0050075.

30. Burdon KL. Fatty material in bacteria and fungi revealed by staining dried, fixed slide preparations. J Bacteriol. 1946;52(6):665-78. https://doi.org/10.112 8/jb.52.6.665-678.1946.

31. Christensen H, Garton NJ, Horobin RW, Minnikin DE, Barer MR. Lipid domains of mycobacteria studied with fluorescent molecular probes. Mol
Microbiol. 1999;31(5):1561-72. https://doi.org/10.1046/j.1365-2958.1999.013 04.x.

32. Rastogi N, Frehel C, David HL. Triple-layered structure of mycobacterial cell wall: evidence for the existence of a polysaccharide-rich outer layer in 18 mycobacterial species. Curr Microbiol. 1986;13(5):237-42. https://doi.org/10.1 007/BF01568645.

33. Nikaido H, Kim SH, Rosenberg EY. Physical organization of lipids in the cell wall of Mycobacterium chelonae. Mol Microbiol. 1993;8(6):1025-30. https:// doi.org/10.1111/j.1365-2958.1993.tb01647.x.

34. Thiam AR, Ikonen E. Lipid droplet nucleation. Trends Cell Biol. 2020;31(2): 108-18. https://doi.org/10.1016/j.tcb.2020.11.006.

35. Thiam AR, Forêt L. The physics of lipid droplet nucleation, growth and budding. Biochim Biophys Acta. 2016;1861(8):715-22. https://doi.org/10.101 6/j.bbalip.2016.04.018.

36. Queval CJ, Brosch R, Simeone R. The macrophage: a disputed fortress in the battle against Mycobacterium tuberculosis. Front Microbiol. 2017;8:2284 https://doi.org/10.3389/fmicb.2017.02284.

37. Walther TC, Farese RV Jr. Lipid droplets and cellular lipid metabolism. Annu Rev Biochem. 2012;81(1):687-714. https://doi.org/10.1146/annurev-biochem061009-102430

38. Ehrt S, Schnappinger D. Mycobacterial survival strategies in the phagosome: defence against host stresses. Cell Microbiol. 2009;11(8):1170-8. https://doi. org/10.1111/j.1462-5822.2009.01335.x

39. Sturgill-Koszycki S, Schlesinger PH, Chakraborty P, Haddix PL, Collins HL, Fok AK, et al. Lack of acidification in Mycobacterium phagosomes produced by exclusion of the vesicular proton-ATPase. Science. 1994;263(5147):678-81. https://doi.org/10.1126/science.8303277.

40. MacMicking JD, Taylor GA, McKinney JD. Immune control of tuberculosis by IFN- $\gamma$-inducible LRG-47. Science. 2003;302(5645):654-9.

41. Armstrong J, Hart PDA. Response of cultured macrophages to Mycobacterium tuberculosis, with observations on fusion of lysosomes with phagosomes. J Exp Med. 1971;134(3):713-40. https://doi.org/10.1084/ jem.134.3.713.

42. Levitte S, Adams KN, Berg RD, Cosma CL, Urdahl KB, Ramakrishnan L. Mycobacterial acid tolerance enables phagolysosomal survival and establishment of tuberculous infection in vivo. Cell Host Microbe. 2016; 20(2):250-8. https://doi.org/10.1016/j.chom.2016.07.007.

43. Botella $\mathrm{H}$, Vaubourgeix J, Lee $\mathrm{MH}$, Song $\mathrm{N}$, Xu W, Makinoshima $\mathrm{H}$, et al. Mycobacterium tuberculosis protease MarP activates a peptidoglycan hydrolase during acid stress. EMBO J. 2017;36(4):536-48. https://doi.org/10.1 5252/embj.201695028.

44. Roque NR, Lage SL, Navarro R, Fazolini N, Maya-Monteiro CM, Rietdorf J, et al. Rab7 controls lipid droplet-phagosome association during mycobacterial infection. Biochim Biophys Acta Mol Cell Biol Lipids. 2020; 1865(8):158703. https://doi.org/10.1016/j.bbalip.2020.158703.

45. Teng O, Ang CKE, Guan XL. Macrophage-bacteria interactions-a lipidcentric relationship. Front Immunol. 2017:8:1836. https://doi.org/10.3389/ fimmu.2017.01836.

46. Houben D, Demangel C, Van Ingen J, Perez J, Baldeón L, Abdallah AM, et al. ESX-1-mediated translocation to the cytosol controls virulence of mycobacteria. Cell Microbiol. 2012;14(8):1287-98. https://doi.org/10.1111/j.14 62-5822.2012.01799.x.

47. Tiwari S, Casey R, Goulding CW, Hingley-Wilson S, Jacobs WR Jr. Infect and inject: how Mycobacterium tuberculosis exploits its major virulenceassociated type VII secretion system, ESX-1. Bacteria Intracell. 2019:113-26. https://doi.org/10.1128/9781683670261.ch8.

48. Barisch C, Soldati T. Breaking fat! How mycobacteria and other intracellular pathogens manipulate host lipid droplets. Biochimie. 2017;141:54-61. https://doi.org/10.1016/j.biochi.2017.06.001.

49. Mattos KA, Lara FA, Oliveira VG, Rodrigues LS, D'Avila H, Melo RC, et al. Modulation of lipid droplets by Mycobacterium leprae in Schwann cells: a putative mechanism for host lipid acquisition and bacterial survival in phagosomes. Cell Microbiol. 2011;13(2):259-73. https://doi.org/10.1111/j.14 62-5822.2010.01533x

50. Zhang C, Yang L, Ding Y, Wang Y, Lan L, Ma Q, et al. Bacterial lipid droplets bind to DNA via an intermediary protein that enhances survival under stress. Nat Commun. 2017:8(1):1-15

51. Peyron P, Vaubourgeix J, Poquet $Y$, Levillain F, Botanch C, Bardou F, et al. Foamy macrophages from tuberculous patients' granulomas constitute a nutrient-rich reservoir for M. tuberculosis persistence. PLoS Pathog. 2008; 4(11):e1000204. 
52. Knight M, Braverman J, Asfaha K, Gronert K, Stanley S. Lipid droplet formation in Mycobacterium tuberculosis infected macrophages requires IFN- $\gamma /$ HIF-1 a signaling and supports host defense. PLoS Pathog. 2018;14(1): e1006874. https://doi.org/10.1371/journal.ppat.1006874.

53. Monson EA, Crosse KM, Das M, Helbig KJ. Lipid droplet density alters the early innate immune response to viral infection. PLoS One. 2018;13(1): e0190597. https://doi.org/10.1371/journal.pone.0190597.

54. Welte MA. Expanding roles for lipid droplets. Curr Biol. 2015;25(11):R470-81. https://doi.org/10.1016/j.cub.2015.04.004.

55. Kaur G, Kaur J. Multifaceted role of lipids in Mycobacterium leprae. Future Microbiol. 2017;12(4):315-35. https://doi.org/10.2217/fmb-2016-0173.

56. Santucci P, Johansen MD, Point V, Poncin I, Viljoen A, Cavalier JF, et al. Nitrogen deprivation induces triacylglycerol accumulation, drug tolerance and hypervirulence in mycobacteria. Sci Rep. 2019;9(1):8667. https://doi. org/10.1038/s41598-019-45164-5.

57. Hammond RJ, Baron VO, Oravcova K, Lipworth S, Gillespie SH. Phenotypic resistance in mycobacteria: is it because I am old or fat that I resist you? J Antimicrob Chemother. 2015;70(10):2823-7. https://doi.org/10.1093/jac/dkv1 78.

58. Zhang Y, Yew WW, Barer MR. Targeting persisters for tuberculosis control. Antimicrob Agents Chemother. 2012;56(5):2223-30. https://doi.org/10.112 8/AAC.06288-11.

59. Sebastian J, Swaminath S, Nair RR, Jakkala K, Pradhan A, Ajitkumar P. De novo emergence of genetically resistant mutants of Mycobacterium tuberculosis from the persistence phase cells formed against antituberculosis drugs in vitro. Antimicrob Agents Chemother. 2017;61(2). https://doi.org/1 0.1128/AAC.01343-16.

60. Aguilar-Ayala DA, Tilleman L, Van Nieuwerburgh F, Deforce D, Palomino JC, Vandamme $P$, et al. The transcriptome of Mycobacterium tuberculosis in a lipid-rich dormancy model through RNAseq analysis. Sci Rep. 2017;7(1):1-13. https://doi.org/10.1038/s41598-017-17751-x.

61. Arbues A, Lugo-Villarino G, Neyrolles O, Guilhot C, Astarie-Dequeker C Playing hide-and-seek with host macrophages through the use of mycobacterial cell envelope phthiocerol dimycocerosates and phenolic glycolipids. Front Cell Infect Microbiol. 2014;4:173. https://doi.org/10.3389/ fcimb.2014.00173.

62. Guerrini V, Gennaro ML. Foam cells: One size doesn't fit all. Trends Immunol. 2019:40(12):1163-79. https://doi.org/10.1016/j.it.2019.10.002.

63. Choi AM, Ryter SW, Levine B. Autophagy in human health and disease. NEJM. 2013;368(7):651-62. https://doi.org/10.1056/NEJMra1205406.

64. Sloan DJ, Mwandumba HC, Garton NJ, Khoo SH, Butterworth AE, Allain TJ, et al. Pharmacodynamic modeling of bacillary elimination rates and detection of bacterial lipid bodies in sputum to predict and understand outcomes in treatment of pulmonary tuberculosis. Clin Infect Dis. 2015; 61(1):1-8. https://doi.org/10.1093/cid/civ195.

65. Kayigire XA, Friedrich SO, van der Merwe L, Donald PR, Diacon AH. Simultaneous staining of sputum smears for acid-fast and lipid-containing Myobacterium tuberculosis can enhance the clinical evaluation of antituberculosis treatments. Tuberculosis. 2015;95(6):770-9. https://doi.org/1 0.1016/j.tube.2015.08.001

66. Bhaskar A, Dwivedi VP, Nandicoori VK. Eliminating mycobacterial persistence: Novel targets for anti-tb therapy. In: Pathogenicity and drug resistance of human pathogens: mechanisms and novel approaches; 2020 p. 57-79.

67. Vilchèze $C$, Jacobs WR Jr. The isoniazid paradigm of killing, resistance, and persistence in Mycobacterium tuberculosis. J Mol Biol. 2019;431(18):3450-61. https://doi.org/10.1016/j.jmb.2019.02.016.

68. Mandal S, Njikan S, Kumar A, Early JV, Parish T. The relevance of persisters in tuberculosis drug discovery. Microbiol. 2019;165(5):492-9. https://doi.org/1 0.1099/mic.0.000760

69. Jones-López EC, Kim S, Fregona G, Marques-Rodrigues P, Hadad DJ, Molina LPD, et al. Importance of cough and $M$. tuberculosis strain type as risks for increased transmission within households. PloS One. 2014;9(7):e100984.

70. Verma S, Bhatt K, Lovey A, Ribeiro-Rodrigues R, Durbin J, Jones-López EC, et al. Transmission phenotype of Mycobacterium tuberculosis strains is mechanistically linked to induction of distinct pulmonary pathology. PLoS Pathog. 2019;15(3):e1007613. https://doi.org/10.1371/journal.ppat.1007613.

71. Wolf AJ, Desvignes L, Linas B, Banaiee N, Tamura T, Takatsu K, et al. Initiation of the adaptive immune response to Mycobacterium tuberculosis depends on antigen production in the local lymph node, not the lungs. J Exp Med. 2008;205(1):105-15. https://doi.org/10.1084/jem.20071367.
72. Ganchua SKC, Cadena AM, Maiello P, Gideon HP, Myers AJ, Junecko BF, et al. Lymph nodes are sites of prolonged bacterial persistence during Mycobacterium tuberculosis infection in macaques. PLoS Pathog. 2018; 14(11):e1007337. https://doi.org/10.1371/journal.ppat.1007337.

73. Kodaman N, Sobota RS, Mera R, Schneider BG, Williams SM. Disrupted human-pathogen co-evolution: a model for disease. Front Genet. 2014;5: 290. https://doi.org/10.3389/fgene.2014.00290.

74. Nuismer SL, Thompson JN. Coevolutionary alternation in antagonistic interactions. Evolution. 2006;60(11):2207-17. https://doi.org/10.1111/j.0014-3 820.2006.tb01858.x.

75. Maji A, Misra R, Mondal AK, Kumar D, Bajaj D, Singhal A, et al. Expression profiling of lymph nodes in tuberculosis patients reveal inflammatory milieu at site of infection. Sci Rep. 2015;5(1):1-10. https://doi.org/10.1038/srep1 5214

76. Mekonnen D, Derbie A, Chanie A, Shumet A, Biadglegne F, Kassahun Y, et al: Molecular epidemiology of M. tuberculosis in Ethiopia: A systematic review and meta-analysis. Tuberculosis 2019, 118:101858, DOl: https://doi. org/10.1016/j.tube.2019.101858.

77. Mekonnen D, Derbie A, Abeje A, Shumet A, Kassahun Y, Nibret E, et al. Genomic diversity and transmission dynamics of M. tuberculosis in Africa: a systematic review and meta-analysis. IJTLD. 2019;23(12):1314-26. https://doi. org/10.5588/ijtld.19.0127.

78. Sharma A, Bloss E, Heilig CM, Click ES. Tuberculosis caused by Mycobacterium africanum, United States, 2004-2013. Emerg Infect Dis. 2016; 22(3):396-403. https://doi.org/10.3201/eid2203.151505.

79. Ates LS, Dippenaar A, Sayes F, Pawlik A, Bouchier C, Ma L, et al. Unexpected genomic and phenotypic diversity of Mycobacterium africanum lineage 5 affects drug resistance, protein secretion, and immunogenicity. Genome Biol Evol. 2018;10(8):1858-74. https://doi.org/10.1093/gbe/evy145.

80. Coscolla M, Gagneux S. Consequences of genomic diversity in Mycobacterium tuberculosis. Semin Immunol. 2014;26(6):431-44. https://doi. org/10.1016/j.smim.2014.09.012.

81. Diarra B, Kone M, Togo ACG, Sarro YDS, Cisse AB, Somboro A, et al. Mycobacterium africanum (lineage 6) shows slower sputum smear conversion on tuberculosis treatment than Mycobacterium tuberculosis (lineage 4) in Bamako, Mali. PloS One. 2018;13(12):e0208603. https://doi. org/10.1371/journal.pone.0208603.

82. Reed MB, Gagneux S, DeRiemer K, Small PM, Barry CE. The W-Beijing lineage of Mycobacterium tuberculosis overproduces triglycerides and has the DosR dormancy regulon constitutively upregulated. J Bacteriol. 2007;189(7):25839. https://doi.org/10.1128/JB.01670-06.

83. Ejo M, Gehre F, Barry MD, Sow O, Bah NM, Camara M, et al. First insights into circulating Mycobacterium tuberculosis complex lineages and drug resistance in Guinea. Infect Genet Evol. 2015;33:314-9. https://doi.org/10.101 6/j.meegid.2015.05.022.

84. Chisompola NK, Streicher EM, Muchemwa CMK, Warren RM, Sampson SL. Molecular epidemiology of drug resistant Mycobacterium tuberculosis in Africa: a systematic review. BMC Infect Dis. 2020;20(1):1-16. https://doi.org/1 0.1186/s12879-020-05031-5.

85. Gehre F, Otu J, DeRiemer K, de Sessions PF, Hibberd ML, Mulders W, et al. Deciphering the growth behaviour of Mycobacterium africanum. PLoS Negl Trop Dis. 2013;7(5):e2220. https://doi.org/10.1371/journal.pntd.0002220.

86. Tientcheu LD, Bell A, Secka O, Ayorinde A, Otu J, Garton NJ, et al. Association of slow recovery of Mycobacterium africanum-infected patients posttreatment with high content of Persister-like bacilli in pretreatment sputum. Int J Mycobacteriol. 2016;5(5):99-S100. https://doi.org/10.1016/j. ijmyco.2016.09.033.

87. Yimer SA, Norheim G, Namouchi A, Zegeye ED, Kinander W, Tønjum T, et al. Mycobacterium tuberculosis lineage 7 strains are associated with prolonged patient delay in seeking treatment for pulmonary tuberculosis in Amhara region, Ethiopa. J Clin Microbiol. 2015;53(4):1301-9. https://doi.org/10.1128/ JCM.03566-14.

88. Garton NJ, Barer MR. Mycobacterial lipid bodies and the chemosensitivity and transmission of tuberculosis. In: Goldfine $\mathrm{H}$, editor. Health Consequences of Microbial Interactions with Hydrocarbons, Oils, and Lipids. Switzerland: Springer Nature; 2020. p. 109-32. https://doi.org/10.1007/978-3030-15147-8_6.

89. Sharma S, Ryndak MB, Aggarwal AN, Yadav R, Sethi S, Masih S, et al. Transcriptome analysis of mycobacteria in sputum samples of pulmonary tuberculosis patients. PLoS One. 2017;12(3):e0173508. https://doi.org/10.13 71/journal.pone.0173508 
90. Ofori-Anyinam B, Dolganov G, Van T, Davis JL, Walter ND, Garcia BJ, et al. Significant under expression of the DosR regulon in M. tuberculosis complex lineage 6 in sputum. Tuberculosis. 2017;104:58-64. https://doi. org/10.1016/j.tube.2017.03.001.

91. Lai RP, Cortes T, Marais S, Rockwood N, Burke ML, Garza-Garcia A, et al. Transcriptomic characterization of tuberculous sputum reveals a host Warburg effect and microbial cholesterol catabolism. bioRxiv. 2020. https:// doi.org/10.1101/2020.03.09.983163.

92. Honeyborne I, McHugh TD, Kuittinen I, Cichonska A, Evangelopoulos D, Ronacher $\mathrm{K}$, et al. Profiling persistent tubercule bacilli from patient sputa during therapy predicts early drug efficacy. BMC Med. 2016;14(1):1-13. https://doi.org/10.1186/s12916-016-0609-3.

93. Garcia BJ, Loxton AG, Dolganov GM, Van TT, Davis JL, de Jong BC, et al. Sputum is a surrogate for bronchoalveolar lavage for monitoring Mycobacterium tuberculosis transcriptional profiles in TB patients. Tuberculosis. 2016;100:89-94. https://doi.org/10.1016/j.tube.2016.07.004.

94. Walter ND, Dolganov GM, Garcia BJ, Worodria W, Andama A, Musisi E, et al. Transcriptional adaptation of drug-tolerant Mycobacterium tuberculosis during treatment of human tuberculosis. J Infect Dis. 2015;212(6):990-8. https://doi.org/10.1093/infdis/jiv149.

95. Bukka A, Price CT, Kernodle DS, Graham JE. Mycobacterium tuberculosis RNA expression patterns in sputum bacteria indicate secreted Esx factors contributing to growth are highly expressed in active disease. Front Microbiol. 2012;2:266. https://doi.org/10.3389/fmicb.2011.00266.

96. Ryndak M, Wang S, Smith I. PhoP, a key player in Mycobacterium tuberculosis virulence. Trends Microbiol. 2008;16(11):528-34. https://doi. org/10.1016/j.tim.2008.08.006.

97. Leistikow RL, Morton RA, Bartek IL, Frimpong I, Wagner K, Voskuil MI. The Mycobacterium tuberculosis DosR regulon assists in metabolic homeostasis and enables rapid recovery from nonrespiring dormancy. J Bacteriol. 2010; 192(6):1662-70. https://doi.org/10.1128/JB.00926-09.

98. Chen T, He L, Deng W, Xie J. The Mycobacterium DosR regulon structure and diversity revealed by comparative genomic analysis. J Cell Biochem. 2013;114(1):1-6. https://doi.org/10.1002/jcb.24302.

99. Rodríguez JG, Hernández AC, Helguera-Repetto C, Aguilar Ayala D, Guadarrama-Medina R, Anzóla JM, et al. Global adaptation to a lipid environment triggers the dormancy-related phenotype of Mycobacterium tuberculosis. mBio. 2014;5(3):e01125-14. https://doi.org/10.1128/mBio.0112 5-14.

100. Honeyborne I, Mtafya B, Phillips PP, Hoelscher M, Ntinginya EN, Kohlenberg $A$, et al. The molecular bacterial load assay replaces solid culture for measuring early bactericidal response to antituberculosis treatment. J Clin Microbiol. 2014;52(8):3064-7. https://doi.org/10.1128/JCM.01128-14.

101. Walter ND, Born SE, Robertson GT, Reichlen M, Dide-Agossou C, Ektnitphong VA, et al. Mycobacterium tuberculosis precursor rRNA as a measure of treatment-shortening activity of drugs and regimens. Nat Commun. 2021;12(1):1-11. https://doi.org/10.1038/s41467-021-22833-6.

102. Demirci M, Saribas S, Ozer N, Toprak S, Caglar E, Ortakoylu G, et al. Diagnostic performance of the RT-qPCR method targeting $85 \mathrm{~B}$ mRNA in the diagnosis of pulmonary Mycobacterium tuberculosis infection. J Infect Public Health. 2018;11(5):662-6. https://doi.org/10.1016/j.jph.2018.02.002.

103. Mukamolova GV, Turapov O, Malkin J, Woltmann G, Barer MR. Resuscitationpromoting factors reveal an occult population of tubercle bacilli in sputum. Am J Respir Crit Care Med. 2010;181(2):174-80. https://doi.org/10.1164/ rccm.200905-06610C.

104. Lipworth S, Hammond R, Baron V, Hu Y, Coates A, Gillespie S. Defining dormancy in mycobacterial disease. Tuberculosis. 2016;99:131-42. https:// doi.org/10.1016/j.tube.2016.05.006.

105. Colangeli R, Gupta A, Vinhas SA, Venkata UDC, Kim S, Grady C et al: Mycobacterium tuberculosis progresses through two phases of latent infection in humans. Nat Commun 2020, 11(1):1-10, DOl: https://doi.org/1 0.1038/s41467-020-18699-9.

\section{Publisher's Note}

Springer Nature remains neutral with regard to jurisdictional claims in published maps and institutional affiliations.

\section{Ready to submit your research? Choose BMC and benefit from}

- fast, convenient online submission

- thorough peer review by experienced researchers in your field

- rapid publication on acceptance

- support for research data, including large and complex data types

- gold Open Access which fosters wider collaboration and increased citations

- maximum visibility for your research: over $100 \mathrm{M}$ website views per year

At BMC, research is always in progress.

Learn more biomedcentral.com/submissions 